\title{
Investigating the factor structure, reliability and validity of the short-form of self-management ability scale in older people
}

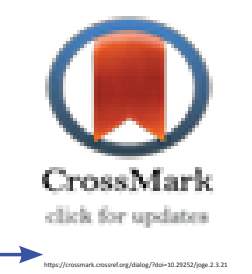 \\ 1- Assistant Professor, Department of Psychology and Educatin, Faculty of Psychologh and Education, Kharazmi \\ University, Tehran, Iran (Correspondence Author) \\ Email: Mehdi_arabzadeh@hotmail.com \\ 2- MA Student, Department of Psychology and Educatin, Faculty of Psychologh and Education, Kharazmi \\ University, Tehran, Iran.

\section{*Arabzadeh $\mathrm{M}^{1}$, Kabiri $\mathrm{V}^{2}$}

\section{Abstract}

Introduction: The investigation of psychometric properties of the short-form of selfmanagement ability scale in older people, including reliability, validity, confirmatory and exploratory factor analysis was the purpose of this study.

Method: In this descriptive- survey study, 283 older people (135 males and 148 females), were selected through available sampling in Tehran. The construct validity of management ability scale was investigated through exploratory factor analysis and main components method by using varimax orthogonal rotation. Reliability of the scale was calculated by test-retest method and ordinal alpha coefficient.

Results: The exploratory factor analysis showed six factors (taking initiative, investing, self-efficacy, variety, multifunctionality and positive frame of mind). Test-retest reliability and internal consistency the ordinal alpha coefficients assumed good.

Conclusion: According to the results of current research, the short-form of selfmanagement ability scale is a reliable instrument with appropriate psychometric properties to measure the rate of self-management ability in Iranian older people.

Keywords: Successful ageing, Healthy ageing, Self-management ability, Selfmanagement of well-being, Factor structure, Reliability and validity.

Received: 26/01/2018

Accepted: 05/02/2018

\begin{tabular}{|l|l|}
\hline \multicolumn{3}{|c|}{ Access this article online } \\
\hline
\end{tabular}




\title{
بررسى ساختار عاملى، روايى و پايايى فرم كوتاه مقياس توانايى هاى خودمدير يتى در سالمندان
}

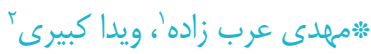 \\ ا- استاديار، كروه روانشناسى، دانشكده روانشناسى و علوم تربيتى، دانشكاه خوارزمى، تمران، ايران (نويسنده مسئول)

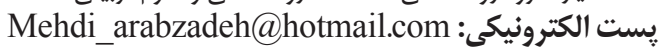 \\ rإ- دانشجوى كارشناسى ارشد روانشناسى تربيتى، دانشكده روانشناسى و علوم تربيتى، دانشكاه خوارزمى، تهران، ايران.

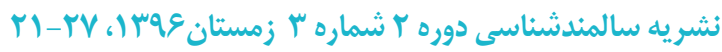

\section{جكيده}

مقدمه: يثوهش حاضر با هدف بررسى ويثگى هاى روان سنجى فرم كوتاه مقياس توانايى هاى خودمديريتى سالمندان، شامل بايايى،

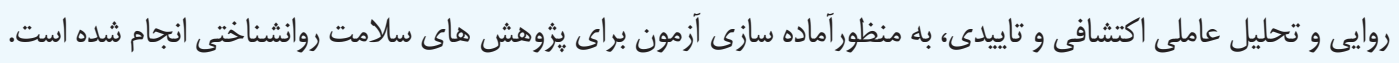

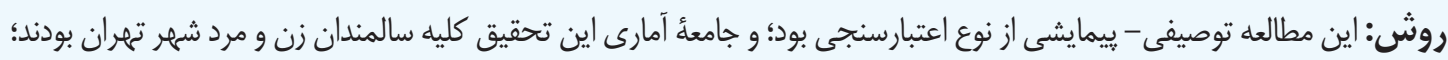

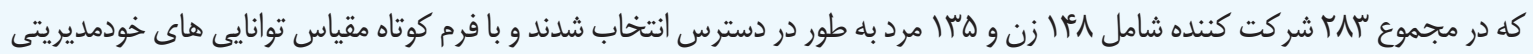

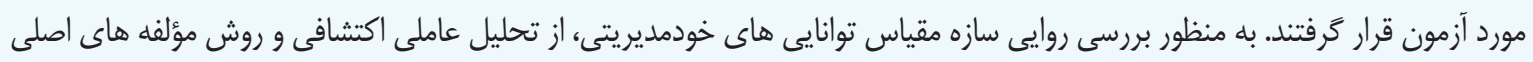

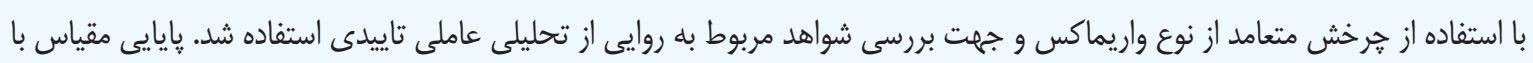

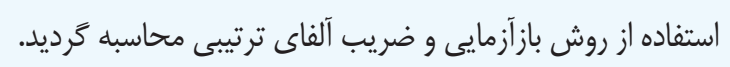

يافته ها: نتايج تحليل عاملى اكتشافى با روش مولفه هاى اصلى، علاوه بر عامل كلى، شش عاريب عامل (نوآورى و ابتكار، رفتار سرمايه

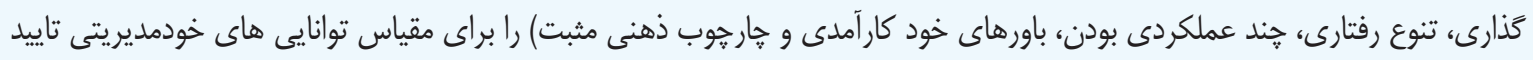

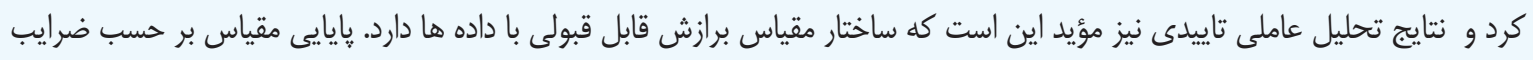

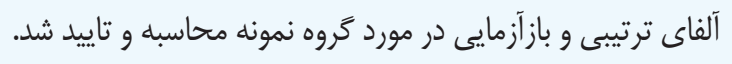

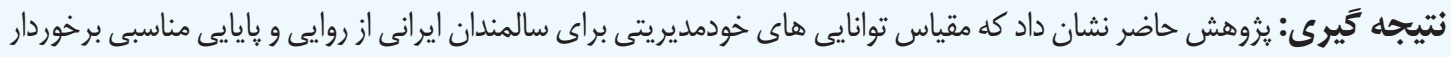

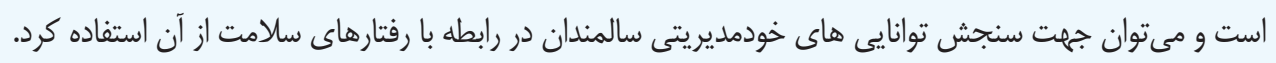

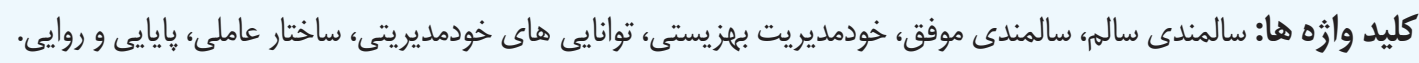


بهزيستى اجتماعى را به همراه مى آوردو نيازهاى فيزيكى در صورت

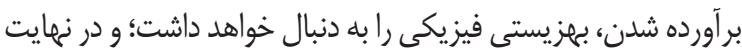
برأورده شدن هر دوى اين نيازها، بهزيستى كلى را به همراه دارد (ه). مهمترين اصل نظريه ى خود مديريت بهزيستى در اين است كه اساسا بايستى سالمندان را به ارتقاى سطوح تحقق نيازهاى

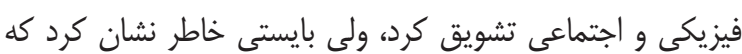

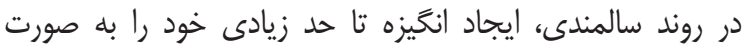
حفظ سطوح تحقق نياز و مديريت شكست ها و ناتوانى ها نشان

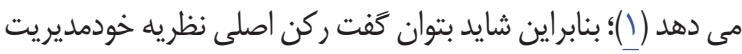
بهزيستى، توانايى خودمديريتى است. توانايى خودمديريتى عبارت است از توانايى هاى كه افراد جهت مديريت منابع براى حفظ سلامتى

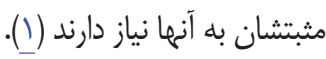
بر اساس نظريه خود مديريتى بجزيستى انسان ها در صورتى مى توانند دوران سالمندى موفقى را تجربه كنند كه با استفاده از توانيى هاى اصلى خود مديريتى يعنى؛ باورهاى خود كارآمدى،

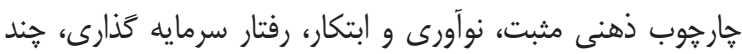

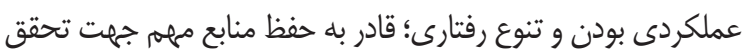
ينج نياز اساسى فيزيكى و اجتماعى يعنى؛ آسودگى خاطر، تحريك،

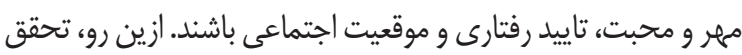

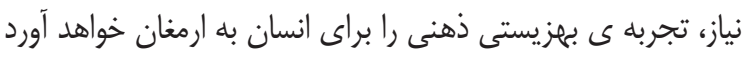

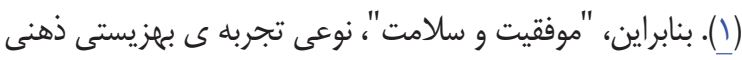

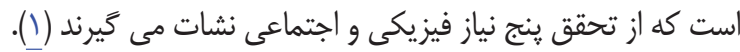
در مجموع در صورتى كه سالمندان از توانايى هاى خود مديريتى خوبى برخوردار باشند، به عبارتى مهارت هايى كسب كنئن

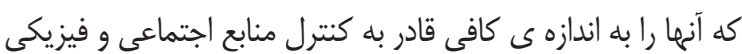
كند، انتظار مى رود كه به بجزيستى فيزيكى و اجتماعى دست يابند،

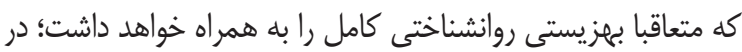
غير اين صورت اكر استقال و قدرت خودمديريتى و تصميم كيرى سالمند به حالش كشيده شود سالمند احساس مى كند كه به به يك موجود زنده بى اختيار و فاقد قدرت تصميم گيرى تبديل شده است و در اين شرايط مجبور است بر خلاف ويزگى درونى خود مطيع

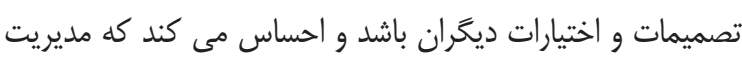
واستقلال او در زندگى اش به خطر افتاده است. اكرجه مطالعات متعددى به بررسى نقش توانايى هاى خودمديريتى در ايجاد بجزيستى و سلامت روانشناختى سالمندان

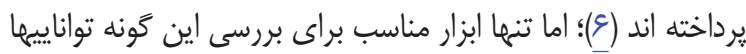
توسط Schuurmanse و همكاران (ه + r) طراحى و اعتباريابى شده است كه در مطالعات متعددى مورد استفاده قرار كَرفته است

\section{مقاله}

سلامتى و بهزيستى (well-being) و تحكَونكَى حفظ آنها تا حداكثر زمان ممكن و تا سنين سالمندى، از ديرباز مورد توجه دانشمندان، سياستخذاران، متخصصين سلامت و حتى خود سالمندان بوده است. روند رو به سالمندى جمعيت، انجام تحقيقاتى براى دستيابى به بينش هاى عملى و مداخلاتى جهت حمايت و خدمت رسانى به تعداد رو به رشد سالمندان را، ايجاب مى كند. در طى على دها كذنشته، عباراتى همجون "سالمندى ساله"، "سالمندى خوب"، "سالمندى فعال" و "سالمندى موفق"، موضوعات راهنما در رشته ى علمى سالمندشناسى و توسعه ى سياست، در خصوص جمعيت

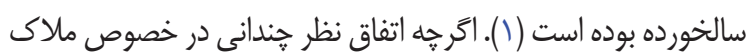

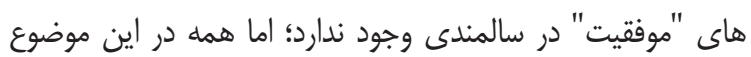
اتفاق نظر دارند كه سالمندى موفق، تنها مربوط به داشتن ثن هاى داى دائ سالم و يا دسترسى به منابع سالم نمى باشد، بلكه به هُخَّنَّى تنظيم زندگى به طور فعال، توسط افراد و رفتارهايشان بستخى دارد، به به بهانه

طورى كه بتوان با آن سلامت و بهزيستى را بهبود بخشيد (؟).

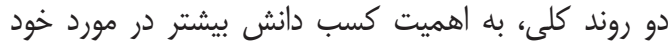

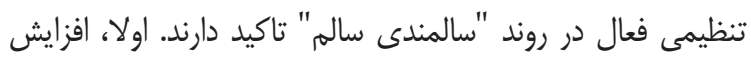
روند ثابت جمعيت ميانسال و تهديد مربوط به تامين مراقبت هاى داى

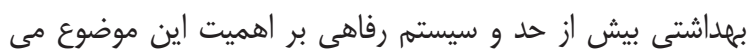
افزايد كه افراد مسن بايستى خودشان قادر به يِيش كرفتن زندكى إنى سالم و شاد تا حداكثر زمان ممكن باشند. ثانيا، موضوع مهم ديخر افزايش اميد به زندگى در سال هاى باقيمانده ى عمر پِ إن از دوران

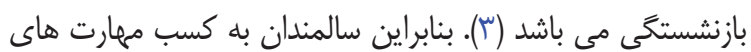

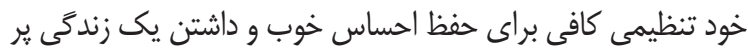
معنى نيازمند هستند.

در سالهاى اخير مدل ها و نظريه هاى مختلفى دربارهى سالمندى موفق و سالم مطرح بوده اند، يكى از مهمترين اين نظريه ها، نظريه ى خود مديريت بهزيستى (self-management)

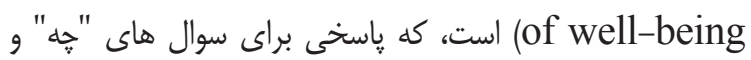

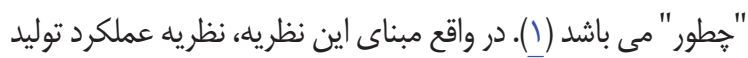

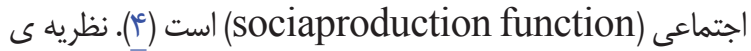
عملكرد توليد اجتماعى، در اصل يك نظريه ى عمومى بهزيستى

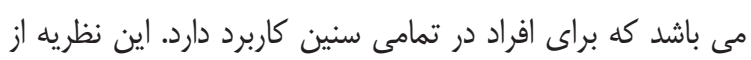
دو فرضيه مهم تشكيل شده است: يكى از فرضيات در مورد نيازهاى ناري اوليه بشر و منابع و اهداف مربوط به آن مى باشد و دومى، در مورد

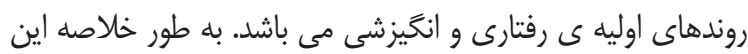

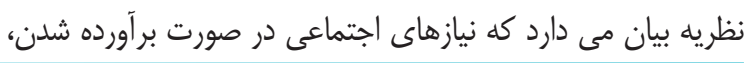


بودند. به منظور بررسى روايى سازه مقياس توانايى هاى خودمديريتى، از تحليل عاملى اكتشافى و روش مؤلفه هاى اصلى با استفاده از جرخش متعامد از نوع واريماكس و جهت بررسى شواهد مربوط به روايى از تحليلى عاملى تاييدى استفاده شد. پايايى مقياس با استفاده

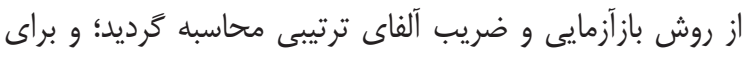

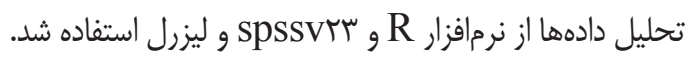
ابزار اندازه كيرى مورد استفاده در اين يزوهش فرم كوتاه

مقياس تواناييهاى خودمديريتى در سالمندان بود كه توسط Cramm

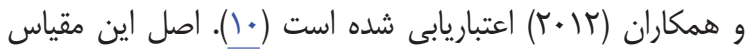

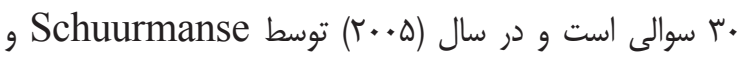
همكاران جهت ارزيابى تواناييهاى خودمديريتى سالمندان ساخته شده

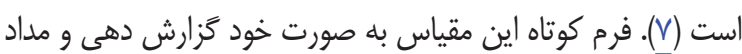

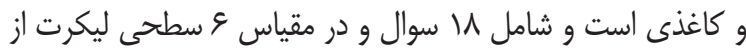

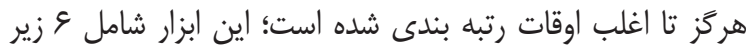

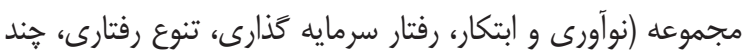

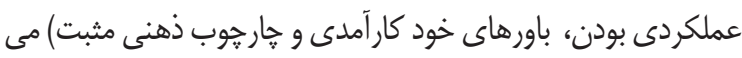
باشدكه در فرم كوتاه هر يك از آنها به جاى ه سوال شامل سار سوال

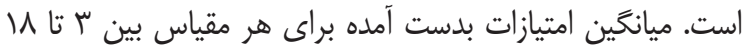

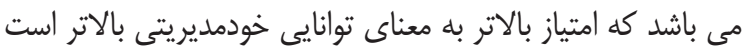

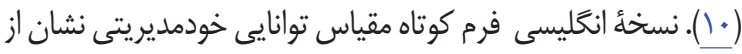

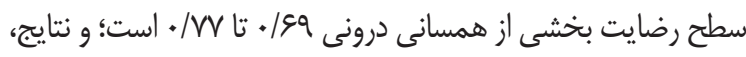

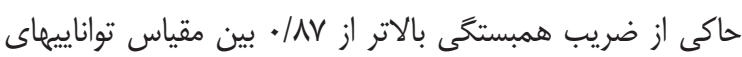
خودمديريتى با مقياسهاى مشابه است؛ و تحليل عامل تاييدى، ساختار به دست آمده از تحليل عامل اكتشافى را تاييد مى كند (•(1).

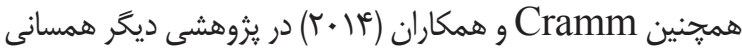

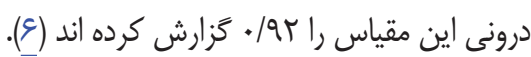
فرايند آماده سازى و استفاده از يرسشناهه هاى كه در فرهنح ديخرى به وجود آمده مستلزم ترجمه و بازترجمه هاى متعددى سرى است كه به منظور كسب اطمينان از معادل بودن مفاهيم برسشنامة اصلى با برسشنامة ترجمه شده صورت مى گيرد. براى بررسى روايى

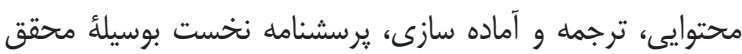
به فارسى بركَردانده شد؛ سبس از ينج نفر متخصص زبان انغلانيسى

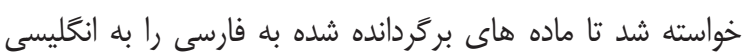
ترجمه معكوس نمايند. آنخاه شكافهاى موجود درتطابق دو ترجمه اصلاح گَرديد. بِ از آن آزمون به دست آمده در تعدادى از شركت

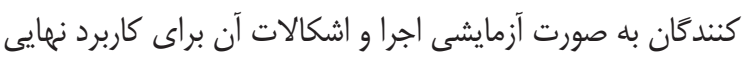
برطرف كرديد و يس از اجراى نهايى تحليل عاملى صورت كرفت.

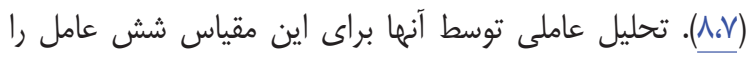
شناسايى كرده است؛ كه به ترتيب عبارتند از: (نوآورى و ابتكار، رفتار سرمايه كذارى، تنوع رفتارى، جند عملكردى بودن، باورهاى خود

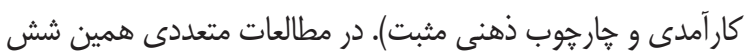
عامل شناسايى شده است (9).

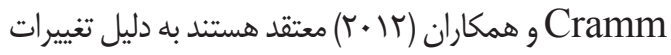
حسى و شناختى در دوران سالمندى جهت ارزيابى سالمندان بهتر است از ابزارهاى استفاده شود كه كوتاه باشند؛ داراى اندازه كَيرى

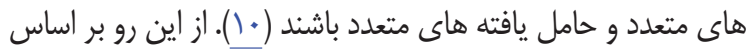

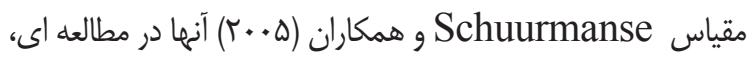

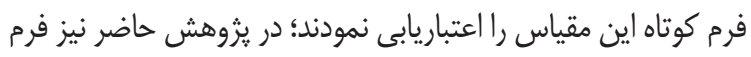
كوتاه اين مقياس در جامعه ايرانى مورد اعتباريابى قرار كر فته است. بنابراين يزوهش حاضر به معرفى و بررسى ويزگى هاى روانسنجى و ساختار عاملى فرم كوتاه مقياس توانايى هاى خودمديريتى سالمندان مىيردازد؛ و اين مسئله ازآنجا ناشى مى فئود كه با توجه به بررسى يُوهشكر در بانكهاى اطلاعاتى موجود،

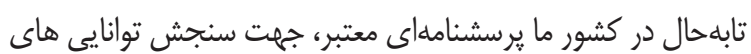
خودمديريتى سالمندان و ابعاد آن به طور خاص تدوين و ترجمه و اعتبار يابى نشده است. از اين رو ارائه برسشنامهاى معتبر مىتواند كمك به رفع اين نقيصه باشد. بنابراين بزوهش حاضر به دنبال

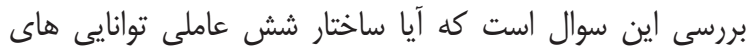
خودمديريتى در سالمندان ايرانى تكرار مى شود؟ و آيا تحليل عامل تاييدى، ساختار به دست آمده از تحليل عامل اكتشافى رادر سالمندان

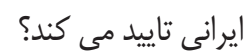

\section{ورش مطالعه}

با توجه به ماهيت مطالعلى حاضر كه بررسى ويزَىهاى روانسنجى و ساختار عاملى فرم كوتاه مقياس تواناييهاى خودمديريتى در سالمندان مى بردازد؛ روش يزوهش حاضر توصيفى- بيمايشى از

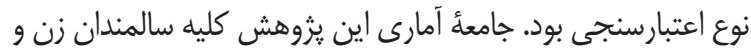

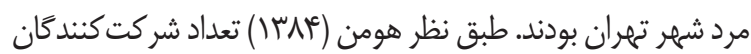

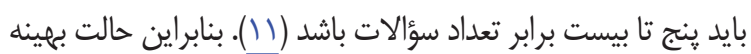

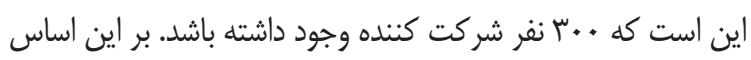

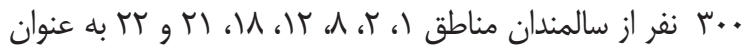
كروه نمونه، به صورت نمونه گيرى در دسترس انتخاب شدند؛ كه در

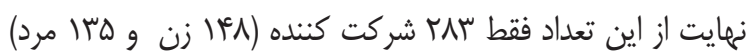
مقياس تواناييهاى خودمديريتى را بطور كامل و درست تكميل كرد ترده 
كنندكان را بر حسب متغير توانايى خود مديريتى و عوامل آن نشان

كافته ها

(جدول () شاخصهاى آمارى ميانكين و انحر اف معيار شركت مى دهد.

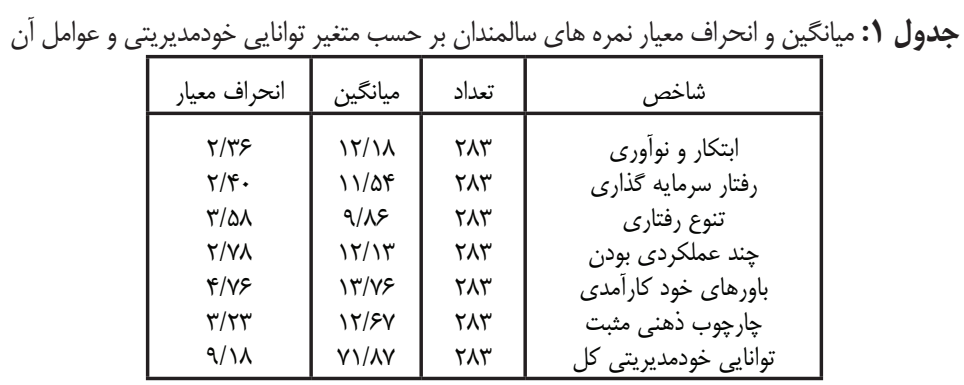

Components Analysis

نخست، قابليت تحليل عاملى از طريق مقياس كايزر - ماير

نوع واريماكس (Varimax) استفاده شد. داده هاى كل نمونه هاى

- اولكين (Kaiser-Meyer-Olkin Measure) و مقياس

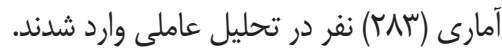

ماده هايى مشمول يك عامل شدند كه وزن •ب//• يا بيشتر

كرويت بارتلت (Barttlet Test of Sphericity) بررسى وفي مقياس

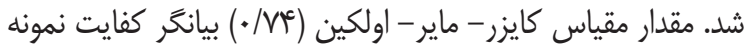

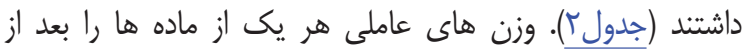

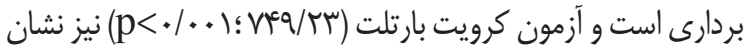

קرخش واريماكس نشان مى دهد. در كل ارزش ويزٔه شش عامل

مى دهد كه ماتريس همبستخى داده ها در جامعه صفر نيست و بنابر اين

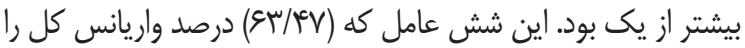

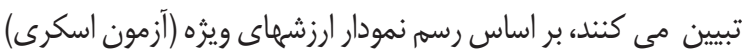
عامل يابى قابل توجيه است. به منظور بررسى روايى سازه مقياس

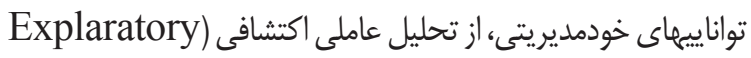
و الكوى وزن هاى عاملى ييشنهاد شدند.

Principal) و و روش مؤلفه هاى اصلى اكتئل (Factor analysis

جدول ؟: نتايج تحليل عاملى ماده هاى مقياس توانايى خودمدير يتى -فرم كوتاه

\begin{tabular}{|c|c|c|c|c|c|c|c|c|c|c|c|}
\hline \multicolumn{2}{|c|}{ (جار يوب ذهنى مثبت) } & \multicolumn{2}{|c|}{ (باورهاى خود پار آمدى) } & \multicolumn{2}{|c|}{ (جند عملكردى بهودن) } & \multicolumn{2}{|c|}{ (تنوع رفتارى) } & \multicolumn{2}{|c|}{ 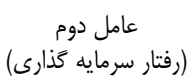 } & \multicolumn{2}{|c|}{ 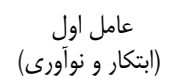 } \\
\hline بار عاملى & ماده & بار عاملى & ماده & بارعاملى & ماده & بارعاملى & ماده & بارعاملى & ماده & بار عاملى & ماده \\
\hline.$/ \$ D$ & 19 & IVQ & سן & IVG & 1. & $.19 \mathrm{~V}$ & $v$ & سو/. & $f$ & או/. & 1 \\
\hline.$/ N I$ & IV & . INT. & 15 &.$/ v 9$ & 11 & .191 & $\wedge$ & .191 & $\Delta$ & . IVQ & $r$ \\
\hline .191 & 11 & . & 10 & $.194^{\circ}$ & Ir & IVG & 9 &.$/ V I$ & 9 & $\cdot|\lambda|$ & $r$ \\
\hline
\end{tabular}

هستند بهترين روش استفاده تحليل عاملى تأييدى است. در اين

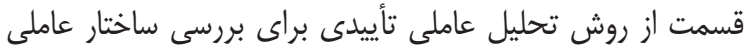

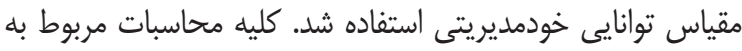

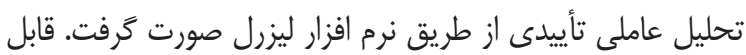

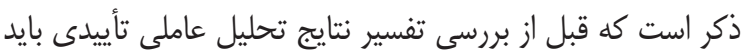

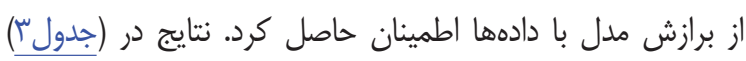
كزارش شده است.
عامل اول شامل ماده هاى (ז، أوّ) عامل دوم شامل

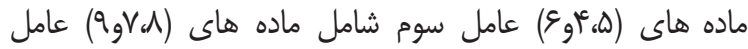

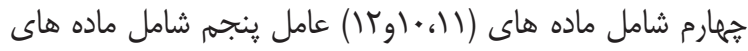

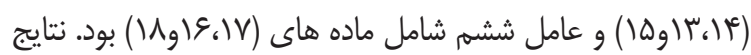
بارهاى عاملى نشان مىدهد كه تمام سؤالات دقيقاً روى عامل مربوط به خودشان داراى بار عاملى معنى دار و بالايى هستند.

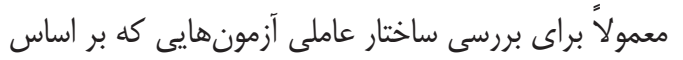

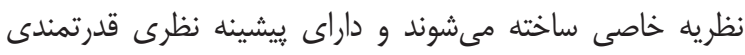

جدول "ا: شاخصهاى برازش مدل شش عاملى با دادهها

\begin{tabular}{|c|c|c|}
\hline مقدار قابل قبول & مقدار به دست آمده & شاخص برازش \\
\hline كوخكتر از ه.|. & $.1 \cdot v \Delta$ & RMSEA \\
\hline بالاى.9. /. &.$/ 91$ & AGFI \\
\hline بالاى .9/. & . & NFI \\
\hline بالاى .9/. & .119 & NNFI \\
\hline بالاى .9/. & -/AV & CFI \\
\hline بالاى • 19. & .194 & IFI \\
\hline
\end{tabular}


نتايج حاصل از ضر ايب عاملى مربوط سؤالات را مورد بررسى قرارداد.

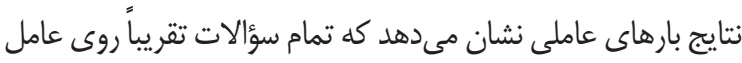
مربوط به خودشان داراى بار عاملى معنى دار و بالايى هستند. براى تعيين پايايى بازآزمايى مقياس، •r نفر به صورت نمونه

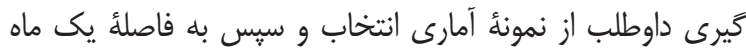

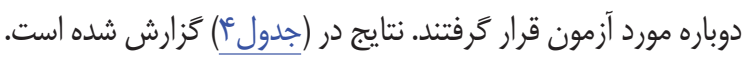
همجنين در (جدول أ) ضريب קايايى كل و خرده مقياسها با استفاده از روش آلفاى ترتيبى نشان داده شده است.
يكى از شاخص هاى اصلى نيكويى برازش در تحليل عاملى

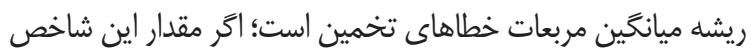
كوجكتر از //• باشد برازندگى مدل بسيار عالى است. اكر بين / /.

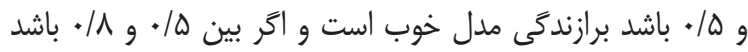

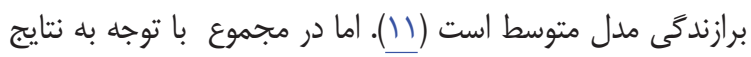
نشان داده شده در (جدولَ) مشخص است كه كليه شاخصهاى برازش مدل با دادهها از مقادير قابل قبولى برخوردار هستند. جون مدل شش عاملى با دادههاى يزوهش برازش دارد بنابراين مىتوان

جدول fا: ضرايب يايايى مربوط به مقياس توانايى هاى خودمديريتى و مولفه هاى آن

\begin{tabular}{|c|c|c|c|c|c|c|c|}
\hline جار «وب ذهنى مثبت & باورهاى خود كارآمدى & جند عملكردى بودن & تنوع رفتارى & رفتار سرمايه كذارى & ابتكار و نوآورى & كل مقياس & مقياس پايايى \\
\hline.$/ V G$ & $\cdot / V^{c}$ & $\cdot / v$. &.$/ 9 V$ & $\cdot / N T$ & $\cdot / \mathrm{N}^{\mathrm{L}}$ & $\cdot|N|$ & باز آزمايى \\
\hline$\cdot|\lambda|$ & . /vG & $\cdot / \mathrm{v} \Lambda$ & .199 & $\cdot|V|$ &.$/ V T$ & $\cdot / \mathrm{NA}$ & همسانى درونى \\
\hline
\end{tabular}

در فرهنَ و جامعه ايرانى ارزيابى كند؛ بر اين اساس مطالعه مبانى

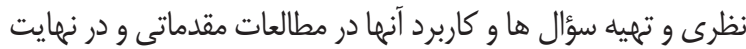

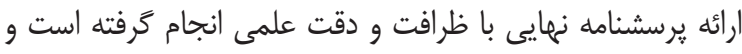
ويرَّيهاى روان سنجى برآورد شده در اين مطالعه و مطالعات ديخر، اين مساله را تأييد مى كند.

\section{نتيجه تيرى نهايى}

نتايج يزوهش حاضر در تاييد بايايى و روايى فرم فارسى

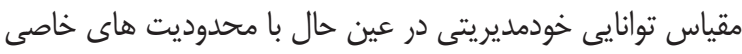

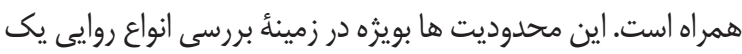
مقياس، كه فرايندى مستمر است، بيشتر نمايان مى شوند. بر اين اين

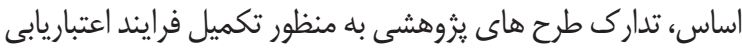

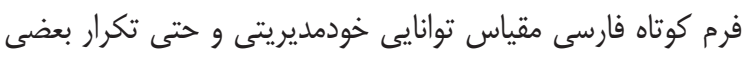

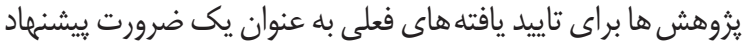

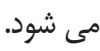

در مجموع، ضرايب اعتبار و روايى مناسب اين يرسشنامه، كوتاه بودن، هند بعدى بودن، سهولت اجرا، شرايط استفاده وسيع

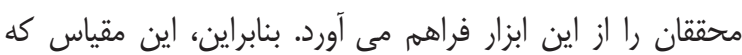

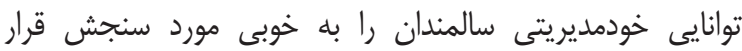
مى دهد، در جامعه ايران اعتبار و روايى مناسبى دارد و مى توانئ داند درد يزوهشهاى سلامت روانشناختى مورد استفاده قرار گيرد.

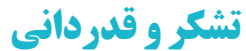

از كليه سالمندانى كه با همكارى و شركت خود در اين يزوهش، محقق را يارى رساندند كمال تشكر و قدردانى به عمل همل

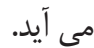

كليه اين ضرايب بيانكر يايايى بازآزمايى خوب مقياس

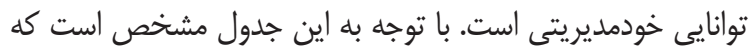

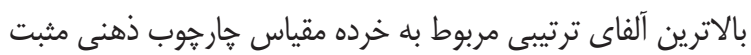

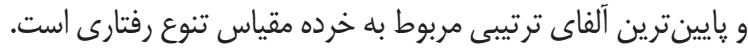

\section{ث}

نقش و اهميت توانايى خودمديريتى در دوران سالمندى دليل واضح دستيابى به ابزارى مناسب در سنجش و وبر بررسى اين توانايى دورني

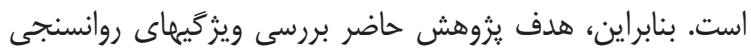
فرم كوتاه مقياس توانايى خودمديريتى در جامعله سالمندى ايران

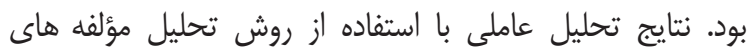

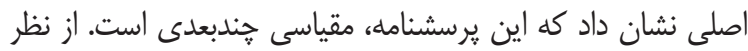
مطالعات بين فرهنگىى، تشابه عوامل استخراج شده با يزوهشهاى Schuurmanse (T) (T)، هم در تعداد و هم در ترتيب، و نيز درصد قابل ملاحظه واريانس تبيين شده به وسيلة عوامل استخراج شده، بيانكر روايى سازه

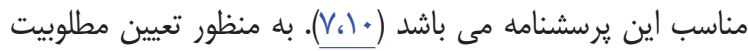

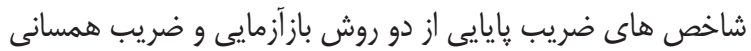

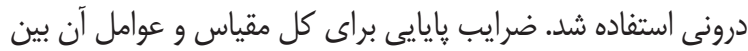

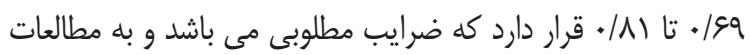
قبلى يعنى Schurmanse و همكاران (ه.+r)؛ Cramm و

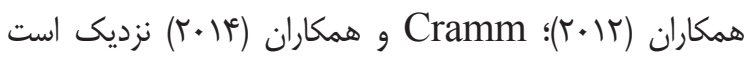
$\left.\left(V_{6}\right) \cdot \mathcal{G}\right)$

يافته هاى اين يزوهش با نتايج يزوهش هاى مرتبط

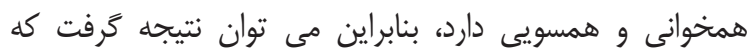
فرم كوتاه اين مقياس هماند فرم اصلى، از بايايى و روايى مناسبى

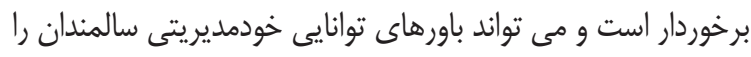




\section{References}

1. Steverink N. Oxford Handbook of Geropsychology. Oxford: Oxford University Press; 2014.

2. Depp C, Jeste DV. Definitions and predictors of successful aging: a comprehensive review of later quantitative studies. Am J Geriatr Psychiatry. 2006; 14 (1): 6-20.

3. Freund AM, Nikitin J, Ritter JO. Psychological consequences of longevity: the increasing importance of self-regulation in old age. Hum Dev. 2009; 52 (1): 1-37.

4. Nieboer AP, Lindenberg S, Boomsma A, Bruggen AC van. Dimensions of wellbeing and their measurement: The SPF-IL Scale. Soc Indic Res. 2005; 73 (3): 313-53.

5. Deci EL, Ryan RM). The "what" and "why" of goal pursuits: Human needs and the self-determination of behavior. Psychol Inqu. 2005; 11(4): 227-68.

6. Cramm J, Twisk J, Nieboer AP. Selfmanagement abilities and frailty are important for healthy aging among community-dwelling older people; a cross-sectional study. BMC Geriatrics. 2014; 14 (28): 1-5.

7. Schuurmans H, Steverink N, Frieswijk N, Buunk BP, Slaets JPJ, Lindenberg $\mathrm{S}$. How to measure self-management abilities in older people by self-report. The development of the SMAS-30. Qual Life Res. 2005; 14 (10): 2215-28.

8. Gholizadeh S, KhankehHR, Mohammadi F. The effect of book therapy on elderly self-management capabilities. Salmand.
2012; 6 (4):51-7.

9. Frieswijk N, Steverink N, Buunk BP, Slaets JPJ. The effectiveness of a bibliotherapy in increasing the selfmanagement ability of slightly to moderately frail older people. Patient Educ Couns. 2006; 61 (2): 219-27.

10. Cramm J, Strating M, Vreede P, Steverink $\mathrm{N}$, Nieboer AP. Validation of the selfmanagement ability scale (SMAS) and development and validation of a shorter scale (SMAS-S) among older patients shortly after hospitalization. Health Qual Life Outcomes. 2012; 10 (9): 1-7.

11. Hooman HA. Structural equation modeling with LISREL application. Tehran: Samt; 2005. 